\title{
十二指腸乳頭炎の病理組織学的検討
}

\author{
東京女子医科大学消化器病センター \\ 福田武隼

\section{HISTOPATHOLOGIGAL STUDY OF DUODENAL PAPILLITIS} \\ Taketoshi FUKUDA \\ The Institute of Gastroenterology, Tokyo Women's Medical Collage
}

\begin{abstract}
要旨 十二指腸乳頭炎について, 乳頭形成術組織標本を主に検索し 剖検例を対象に病理組織学的検討を行つ た。乳頭部組絒学的所見を, 乳頭部粘膜の変化, 壁内腺管の変化, 間質と筋組織の変化, 細胞浸潤, 破壊性変 化（結石によつてもたらされたと思われるびらん，潰鎄），十二指腸粘膜の変化の各項目について，乳頭粘膜の 過形成, 壁内腺管の増生・拡張・のう胞形成, 間質の線維化・硬化, 筋線維の変性・萎縮と仮性肥厚, 細胞浸 潤の程度，破壞性変化による組織反応，十二指腸粘膜の過形成などについて，それぞれ比較検討し，炎症によ つてもたらされた主な組織変化を導きだした。この成績に基づいて慢性乳頭炎を過形成性乳頭炎, 腺のう胞性

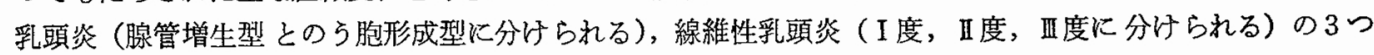
の型とその亜型とに分類した。この分類は生体の基本的反応態度を考虑し，炎性变化と乳頭部組織の反応ない し病変との関保を時間的推移を加味して分類したものである.さらに肝内胆管, 総胆管, 乳頭部の関俰, 乳頭 部組織変化と加齢との関係について言及した。
\end{abstract}

\section{I. 緒 言}

十二指腸乳頭部は胆膵管が合流し䏣汁, 膵液の排出管 としてその流出を営む機構であり, 病態生理的にも組織 病理学的にる重要な役割を果している.したがつてこの 部の病変は, 肝・胆道・膵などの周团藏器と密接な関係 を有していると考党られる。

1926年, del Valle ${ }^{11}$ により胆のう剔出術後患者で乳頭 部の可逆的岕るい恃不可逆的な狭窄性変化の存在が指摘 されて以来, この部の病変は, 主として外科領域に括い て臨床的検索や胆道手術時の生検, 切除標本による組織 学的検討が行われてきた. Acosta ${ }^{2)}$ は反復せる乳頭部の 炎症性変化は終局的には総胆管末端部の不可逆的な狭窄 をひき扣こすが，また急性ない乙亜急性の炎症性变化が 同時に可逆的な狭窄をひき括こすことの可能性について 報告した。本邦に批いても, 槙 ${ }^{33}$ が胆道疾患に和いては 胆のうそれ自体よりもOddi 筋の異常挛縮ないしはその 病変に真の原因を有しているものが多いとして乳頭部病 変を重視した。この様に乳頭部の機能と形態についてさ まざまな検討がなされているが，しかし乳頭部の解剖学 的定義についても一定の見解が得られず，また乳頭炎の
組織学的なとらえ方についても現在なお一致していな い.そこで乳頭部を胆道・脺・十二指腸との organ complex としての基盤に立つて, 乳頭部を総胆管の十二指 腸壁貫通部より十二指腸開口部までと定義して検討を行 つた. 乳頭形成術施行例の検索に苏たつては, 乳頭部の 組織構成にしたがい炎症像とそれによつてもたらされる 組織変化を時間的経過を加味して検索した.

\section{II. 検索材料と検索方法}

検索材料は乳頭狭窄症と総胆管昖張症の臨床訅断で乳 頭形成術を施行した 31 例 (肝内胆管と総胆管の部分切除 を同時施行した 3 例を含む)である. 組織解剖学的な構 造の検討をするためには，胆道疾患とは関係なき剖検例 7 例を用いた。乳頭形成術標本は総胆管にそつて約 2.0 $\sim 3.0 \mathrm{~cm}$ 楔状切除標本である. 切除標本は肉眼的観察 を行つた後，濾紙にはり10\%フォルマリン液で固定， Hematoxylin-Eosin 染色を主とし, 特殊染色としてP A T H染色, Azan-Mallory染色, 鍍銀染色を行つた。粘液 染色としてAlcian-Blue PAS 染色を主に用いた。

十二指腸乳頭部の変化を乳頭部粘膜上皮の過形成, 壁 内腺管の増生拡張 -のう胞形成, 間質の線維化硬化, 竻 
組織の变化, 炎性細胞浸潤の程度, 乳頭部に打けるびら ん・潰瘍の有無と十二指腸粘膜の变化の 7 項目を中心に 検討した，剖検例については年令的要素に注目し検討対 照症例とした。

\section{II. 検討成縝}

\section{A. 乳頭部の組織学的所見}

1. 乳頭部粘膜の変化

乳頭部粘膜は比較的密で丈の高い乳頭状，あるいは䄉 毛状を呈し敡壁ともい学る構造を形成する。したがつ て, この粘膜は弁をむかねた構造となつて円筒状に内腔 飞向つて增生する（写真 1，2). 粘膜の腺上皮は一層の 円柱上皮よりなる。この上皮には硝子縁をもつ腸上皮様 粘膜と硝子縁を欠く胃上皮様粘膜が観察され，硝子縁の ない胃上皮様粘膜上皮の粘液には P A S 陽性の顆粒が証 明される。

粘膜上皮を過形成の程度によつて高度，中等度，軽 度と分壮た。過形成の強い高度（卅）は 4 例（症例 1 , $2,3,4)$ ，中等度 (H) は 8 例（症例 $5,8,9$ ， $18,19,27,29,30$ ), 軽度 (十) は12例 (症例 6,7 , $12,13,14,16,20,21,22,23,25,28)$ であつた. 一方, 粘膜の萎縮をみるものは 7 例（症例 $10 ， 11 ， 15$, $17,24,26,31$ ) であつた（表 1). 乳頭粘膜の過形成 性高度の症例 4 例（症例 $1 ， 2 ， 3 ， 4$ ）の粘膜上皮は 乳頭状の増生を顕著に示した (写真 3 ).この 4 例をみる と乳頭部組織全体に過形成性の所見が認められ, 壁内腺 管にも 4 例全例に軽度末たは中等度の腺管增生が認めら れた。間質および筋組織の変化はほとんどみられず, 全 体として乳頭部の組織構造はほ汴正常に保たれていた。 炎性細胞浸潤をみると，症例 1，2 亿はごくわずかの多 形核白血球浸潤が併存し急性炎の存在もらかがわれた。 症例 $2 ， 3$ には慢性炎性細胞漫潤を軽度に認めた。十二 指腸粘膜についてみると, 症例 1 のみに十二指腸粘膜の 過形成が観察された。乳頭粘膜過形成中等度の症例は 8 例（症例 $5,8,9,18,19,27,29,30$ ) で，8例中 症例27のみが壁内腺管の高度 (H) 増生を, 4 例（症例 $8,9,18,19)$ 飞中等度 (十) 増生を認め, のこり 3 例（症例 5，29，30）では壁内腺管增生は軽度もしくは みられなかつた。乳頭部粘膜の過形成が軽度 (十)のも のは12例（症例 $6,7,12,13,14,16,20,21,22$, $23,25,28$ ) で, このうち5例（症例 $6,7,13,14$, 28）が壁内腺管の高度 (H) 增生を， 7 例（症例， 12, $16,20,21,22,23,25)$ k中等度 (十) 増生を認 め た。乳頭粘膜の過形成がなく著縮を認 めた症例は 7 例
表 1 乳頭部の組織変化

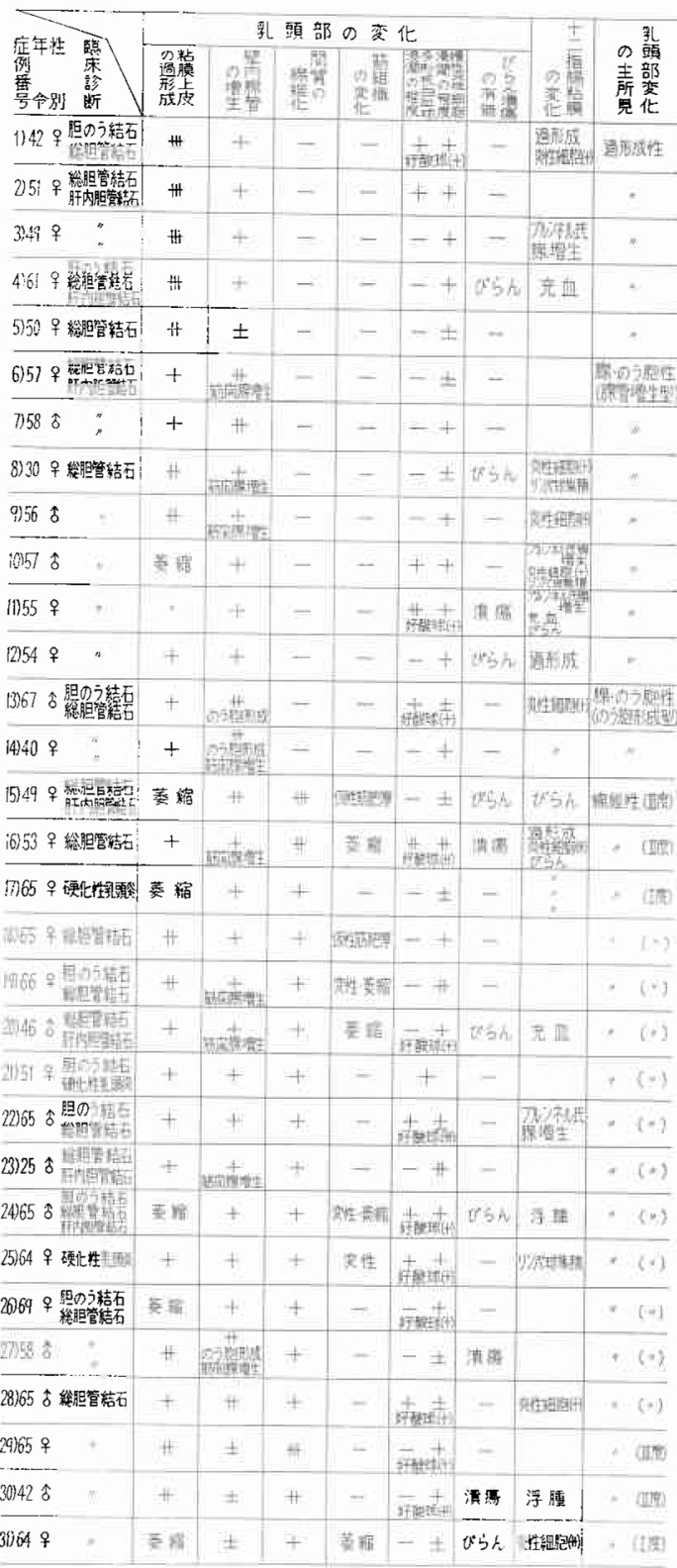

（症例 $10 ， 12 ， 15 ， 17,24,26 ， 31$ )で, この5ち壁内 腺管の高度 (H) 增生例は 1 例（症例15）の及で， 5 例 （症例10，11，17，24，26）火中等度（+）増生を，1 例（症例31）には壁内腺管增生は認められなかつた。

以上の所見から乳頭粘膜の過形成性変化を主とする症 例(症例 1，2，3，4，5)では乳頭部組織全体に過形 成性の傾向が示され組織構造はほぼ正常に保たれ，間質 
の变化はほとんど認められないことがわかつた。また乳 頭粘膜上皮全体の過形成性傾向と十二指腸粘膜の過形成 は必ずしも一致しなかつた。乳頭粘膜過形成高度の 4 例 では乳頭粘膜過形成と壁内腺管增生とが平行した。乳頭 粘膜過形成が中等度または軽度例では他の組織变化が加 わり乳頭粘膜過形成之他の組織変化は必ずしも一致しな かつた。乳頭粘莫萎縮症例には壁内腺管の增生は軽度も しくは增生が認められなかつた。しかし過形成高度例と 異つて他の組織変化と平衡関係はみられなかつた。

2. 壁内腺管の変化

乳頭組織構造で粘膜，粘膜下層は必ずしも明確にされ ないが粘膜上皮下を粘膜下層とすれば，この部には主と して粘液腺つまり壁内腺管が観察され間質は蹯な結合織 よりなる（写真 1，2，3）. 壁内腺管は増生すると腺腔 の数を増し腺細胞の丈は高くなり粘液形成能も增加寸る ようである.変化が強くなると, 増生した壁内腺管は蛇 行払張を示し, 時浪の胞形成も呈する。この際, 立方 状，円柱状の腺細胞は丈が低く扁平となる．また壁内腺 管が筋層内に侵入增生する像が観察されるが，この際に は筋線維の装性萎縮を伴らことが多く筋間結合織の増生 を随伴する。

壁内腺管の増生をその程度により, 高度 (H), 中等度 (十),軽度もしくは洼とんど認められないもの（士）と 3段階に分けた。壁内腺管增生高度 (H) むのは7例 (症例 $6,7,13,14,15,27,28$ ), 中等度 $(+$ ) のも のは20例（症例 $1,2,3,4,8,9,10,11,12$, $16,17,18,19,20,21,22,23,24,25,26)$, 軽度も しくは汪とんど認められないもの（士）は4例（症例 5，29，30，31）である. 壁内腺管の高度ない乙中等度 増生を主たる所見とし，間質の線維化を認めない症例は 症例 $6 \sim 14$ の 9 例で, このうち壁内腺管の数の増生と拡 張を特徵とする腺管增生例（腺管增生型とする）（写真 4) は症例 6〜120 7 例で, 壁内腺管の増生拡張ととも Kのう胞状変化を特徽とするのう胞形成例(のう胞形成 型とする）（写真 5 ）は症例 $13 ， 1402$ 例であつた. 腺 管増生型 7 例とのう胞形成型 2 例について乳頭粘膜上皮 との関係をみた。腺管增生型では乳頭粘膜中等度過形成 2 例（症例 $8 ， 9$ ), 軽度過形成 3 例（症例 6, 7, 12）, 萎縮 2 例（症例10，11）であつた。のう胞形成型の 2 例 はいずれも乳頭粘膜には軽度過形成が認められた。筋層 々の関係をみる之, 笳層内への壁内腺管侵入増生が腺管 増生型 7 例中 3 例（症例 $6 ， 8 ， 9 ） に ， の 5$ 胞形成型 2 例中 1 例（症例14）にみられ，いずれの症例にも筋層
の肥厭や筋線維の萎縮はみられなかつた。壁内腺管増生 が認められないか，認められてもごく軽度の症例（症例 $5 ， 29,30,31)$ 飞は筋層内壁内腺管侵入增生は認めら れなかつた。炎性細胞浸潤についてみると，多形核白血 球浸潤が腺管增生型の 7 例中 2 例（症例 $10 ， 11 ）, 05$ 胞 形成型 2 例中 1 例（症例13）に認めら㣗急性炎の合併が らかがわれた。他の症例についてみると慢性炎性細胞浸 潤は比較的軽度であつた。 十二指腸粘膜の変化について 及ると, 腺管增生型 7 例中 1 例（症例12）に過形成, 2 例（症例10，11）にブルンネル氏腺增生 2例（症例 $8 ， 10 ）$ Kンパ球集積を認めた。

以上の所見より，壁内腺管增生を主所見とする症例 （症例 6 ～14）火沶いて腺管增生型の 3 例とのう胞形成 型の 1 例に筋層内への壁内腺管侵入増生を認めたが，他 の5 例では正常構造を乱す所見は汪とんど認められなか つた。急性炎を 3 例に認めたが，他の 6 例恃慢性で炎性 細胞浸潤は比較的軽度であつた。つまり，間質の線維化 を認めなかつた壁内腺管增生例，のう胞形成例はとりた てて病変とすべき組織所見に乏しかつた。

3. 間頃の変化と筋組織の変化

間質の線維化・硬化の程度を高度 (卅), 中等度 (H), 軽度（十）に分㲿た。線維化・硬化高度のものは 2 例 （症例15，29）である. 粘膜上皮の過形成は症例29で中 等度にみられたが (写真 6), 症例15では乳頭粘膜の萎縮 をみた。壁内腺管增生は症例15で中等度に認め腺管増生 型であつた。症例29では壁内腺管增生は注とんど認めら れなかつた。筋組織の变化についてみると, 症例15で筋 層の肥厚を認めたが，この筋肥厚は結合織染色を行つて みると筋間結合織増生による仮性筋肥厚であつた。症例 29では筋組織の変化は恬とんどみられなかつた。炎性細 胞浸潤炕ついてみると 2 例ともごく軽度の慢性炎性細胞 浸潤を認めたにすぎない。また十二指晹粘膜には渒と九 ど変化が諗められなかつた。線維化・硬化中等度の症例 は2 例(症例16，30)である.粘膜上皮の過形成は症例16 で軽度, 症例30で中等度に2られた。壁内腺管增生は症 例16で中等度にみられ腺管堌生型で筋層内一の壁内腺管 侵入增生を認めた。症例30では壁内腺管增生は活とんど みられなかつた，筋組織の変化についてみると, 症例16 江筋線維の萎縮を認めたが症例30では活とんぞ変化を認 めなかつた。炎性細胞浸潤についてみると, 症例16では 潰瘍形成に伴ら急性ならびに慢性炎性細胞浸潤を中等度 に認めたが，症例30では慢性炎性細胞浸潤のみが軽度に みられた。 十二指腸粘膜の変化についてみると, 症例16 
では粘膜の過形成とびらん形成に伴う中等度の炎性細胞 浸潤を認めた．線維化・硬化軽度のものは13例(症例 17 , $18,19,20,21,22,23,24,25,26,27,28,30)$ で ある.これら13例についてみると，乳頭粘膜上皮の過形 成は 3 例（症例18，19，27）で中等度に，6例（症例 $20,21,22,23,25,28$ ) で軽度， 4 例（症例17，24, 26，31）で萎縮を認めた. 壁内腺管の増生は10例（症例 17〜26）で軽度にみられ，いずれも腺管增生型である が，2例（症例27，28）は壁内腺管増生中等度での5胞 形成型であつた。筋䅉内への壁内腺管侵入増生は 4 例 （症例19，20，23，27）にみられた. 筋組織の変化につ いてみると，症例15，18で仮性筋肥厚を，症例16，19， 20,24, 31 で筋線維の萎縮を, 症例25で筋線維の変性を 認めた，急性炎性細胞浸潤は症例 $20 ， 22 ， 24 ， 25 ， 28 の$ 5 例で軽度にみられ, 慢性炎性細胞浸潤は軽度もしくは 中等度にみられた。十二指腸粘膜の変化は症例17で過形 成と中等度の慢性炎性細胞浸潤を認め, 症例22でブルン

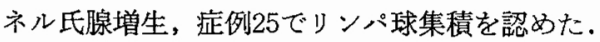

以上の所見より，線維化・硬化軽度の症例については 乳頭粘膜過形成, 壁内腺管增生の傾向を認めたが, 線維 化・硬化中等度もしくは高度の症例では過形成性傾向は 認められなかつた。筋層内への壁内腺管侵入堌生は, 線 維化・硬化の有無とは関係なく, 壁内腺管の増生の強さ に関保していた，等層の変化は線維化・硬化を伴つた症 例にのみ著しく, 線維化・硬化症例の約半数に筋の変性 萎縮, 仮性肥厚なぞの変化を認めた. 残り半数では筋組 織の变化は認めなかつた. 線維化・硬化の程度と炎性細 胞浸潤の関係をみると, 線維化・硬化高度例には急性炎 性細胞浸潤は認められず, 慢性炎性細胞浸潤も軽度も乙 くははとんぞ認められなかつた。線維化・硬化中等度例 では，1例が潰惕形成に伴う中等度の急性慢性細胞浸潤 を認めたが，他の1例では慢性炎性細胞浸潤の及が軽度 にみられたにすぎない，線維化・硬化軽度例においても 結石を有するびらんもしくは潰場併存例に急性炎性細胞 浸潤を認めたが，全般的にみると炎性細胞浸㵎は比較的 に軽度であつた。

\section{4. 炎症紐胞浸潤}

正常では乳頭部粘膜および粘膜下にはリンパ球，プラ スマ球等の慢性小円形細胞が検鏡される。炎性細胞浸潤 は十二指腸粘膜に認められるそれよりる少ない。乳頭部 の咨症例注形核白血球浸潤を伴う急性炎, プラスマ 球を中心とする慢性炎があり, 消炎時の組織像には好酸 球が比較的多く観察された.
多形核白血球浸潤は 2 例（症例11，16）で中等度に, 9 例（症例 $1 ， 2 ， 10,13,20,22,24,25,28$ ) で軽 度にみられた。慢性炎性細胞浸潤は 3 例（症例16，19， 23）で中等度に18例（症例 $1 ， 2 ， 3 ， 4 ， 7 ， 9$ ， $10,11,12,14,18,20,21,24,25,26,29,30)$ で 軽度にみられた。好酸球浸潤は 3 例（症例16，22，30） で中等度に，9例（症例 $1 ， 11,13 ， 19 ， 20,24 ， 25$, 26，28）で軽度にみられた。急性慢性炎性細胞浸潤の強 さと乳頭粘膜上皮の変化，壁内腺管の変化についてみた が，細胞浸潤の強さと粘膜上皮，壁内腺管の変化とは必 ずしも一定の傾向はみられなかつた，急性炎性細胞浸潤 々線維化・硬化との間にも一定の関係は認められなかつ た，急性炎は破壞性病变に伴うものが多く観察され，び らん形成の 7 例（症例 $4,8 ， 12 ， 15,20,24,31$ ) 中 2 例（症例20，24）K, 潰瘍形成の 4 例（症例11，16， $27,30)$ 中 2 例 (症例 11,16 ) 飞多形核白血球浸潤を認 ぬた。慢性炎性細胞浸潤と線維化・硬化飞ついてみる と, 炎性細胞浸潤中等度の症例は, 線維化・硬化中等度 の 1 例（症例16）之線維化 - 硬化軽度の 2 例（症例19, 23）にみられた。炎性細胞浸潤軽度の症例は，線維化 - 硬化高度の 1 例 (症例29), 線維化 - 硬化中等度の 1 例 (症例30), 線維化 - 硬化軽度の 6 例（症例18，20，21， 24，25，26）に友られた。慢性炎性細胞浸潤のほとんど 認められない症例は, 線維化・硬化高度の 1 例（症例 15）線維化・硬化軽度の 5 例 (症例 $17,22,27,28$, 31)にみられた.

以上の所見より，炎性細胞浸潤の程度は炎症の強弱を 現わするのであつて，乳頭粘膜上皮の変化，壁内腺管の 变化とは必ずしも一致しない，急性炎性細胞浸潤は破壊 性病変と関係するすのが多くみられた。慢性小円形細胞 浸潤は全例浔認められたが，線維化・硬化の程度の強い わのほど少ない傾向があつた。

5. 破填性変化 (びらんと潰瘍)

乳頭部組織の变化には资性組織变化に加えて胆石によ る破壊性変化として，びらんと潰瘍が考虑されねばなら ない,とくに乳頭部への結石の嵌入または嵌頓例には総 胆管末端の生理的狭㴼部に潰瘍が認められた。結石によ る破壊性変化は, 単に急性びらんというょり, むしろ組 織学的に反応が高度で亜急性もしくは急性の炎性びらん と考えたい症例が認められた。びらんが認められた症例 は 7 例（症例 $4,8,12,15,20,24,31$ ）であつた. これら 7 例中 5 例 (症例 $4,8,12,15,31$ ) に亜急 性炎を思わせる血管結合織反応が強く，2 例（症例20, 
24）飞は急性炎症を思わせる多形核白血球浸潤を主に認 めた。潰瘍形成は 4 例(症例 $11 ， 16 ， 27 ， 30$ ) Kみられた (写真 7).潰瘍はいずれも慢性潰瘍の像を呈し乳頭部の 胆管側（総胆管末端の生理的狭窄部）飞認められた。慢 性潰痬形成の 4 例中 2 例（症例 11，16） は急性炎症む強 〈2られ，多形核白血球浸潤，好酸球浸潤を中等度汇認 めた. びらん形成の 7 例之潰暗形成の 4 例いずれる臨床 上総胆管に結石を有し，これら破壊性変化に結石が関係 てていると思われる。びらん形成の 2 例（症例 8，20） には結石嵌頓によると思われるビリルビン系の色素がび らん周囲にみられた。びらん，潰場と間質の線維化・硬 化との関係をみると,びらん形成の 7 例中 4 例に軽度の 線維化・硬化を，1例傐度の線維化・硬化を認めた。 また潰㾝形成の 4 例中 2 例沈中等度の線維化・硬化， 1 例烧度の線維化・硬化を認めた。

したがつて、この結果からみると、びらんをたは潰瘍 の破壊性病变は結石によつてもたらされた修飾的病変で 本来の炎症とは異つた意味をるつものであることがわか る. しかし結石例が多数であり,びらん・溃瑒は重視し なければならない，このような症例では間質の線維化 ・硬化に平行関係があることがわからた。

6. 十二指腸粘膜の変化

十二指腸粘膜と乳頭部粘膜とは自然に移行する。十二 指腸粘膜と乳頭部の腸上皮様の粘膜とが区別しにくいこ ともあるが, 乳頭粘膜は開口部附近で乳頭状の特殊な構 造を呈するので比較的容易に区別でき乳頭部粘膜が P A $\mathrm{S}$ 陽性の性質を有する胃上皮様構造を呈する場合はさら に明瞭に区別できる。

十二指腸粘膜 過形成性变化は 4 例（症例 1,12 , 16，17）飞みられた.これら 4 例中 1 例（症例 1）のみ が乳頭部粘膜の過形成性変化と一致するが，2 例（症例 12，17）では乳頭粘膜の萎縮をみた。ブルンネル腺增生 （症例 3,10，11）、ソパ球集積（症例 8，10，25）, 充 血(症例 4,11，20), 浮隀 (症例24, 30)などの所見は 乳頭部の炎性所見とは必ずしも一定の関係はなからた。 十二指腸粘膜にびらんおよびびらんの治㾉像がみられた 4 例（症例11，15，16，17）の中で 3 例（症例11，15, 16）飞乳頭部にびらんまたは潰䀛が認められた。

以上の所見より, 全体として乳頭部の炎性変化と十二 指腸のそれとが必ずしも平行せず，粘膜の過形成変化に ついても同様のことがい克る。しかし，結石によると思 われるびらん括よび潰瘍の破壊性変化は十二指腸粘膜に もまた破壊性変化をもたらすようである。
7. 肝内胆管, 総胆管, 乳頭部の関係

肝内胆管, 粉胆管, 乳頭部の組織標本が得られた 3 症 例（症例 $3,20,23$ ) 飞ついて, 乳頭炎が総胆管の限局 性炎症であるか汎胆管炎であるか注目してその組織変 化をみた（表 2).組織の構成より，まず粘膜上皮の変化 をみると, 肝内胆管の粘膜は一層の円柱上皮でとくに変 化をみない，総胆管粘膜はいずれも結石によると考兄ら れる上皮の脱落を観察して括り一部に一層の円柱上皮を 認めた。一方, 乳頭部粘膜上皮はすべて過形成珄の変化 を示した. 胆管壁の変化についてみると, 肝内胆管では

表 2 胆内䏣管・総胆管・乳頭部の組織変化の関係

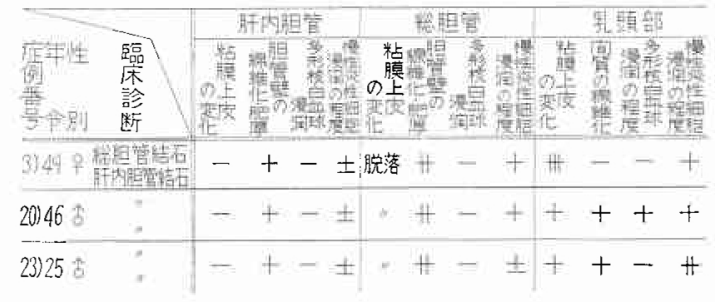

胆管壁の線維化・肥厚が軽度に認められ, 総胆管壁では 線維化・肥厚は中等度ないし高度にみられた。一方, 乳 頭部の間質の線維化は 2 例で軽度に認められ，1 例では 線維化は認められなかつた。炎性細胞浸潤についてみる と多形核白血球浸潤は，3例ともと肝内胆管，総胆管飞 はみられず，乳頭部では 1 例に認められた。慢性炎性細 胞浸潤は肝内胆管ではほとんど認められず，総胆管では 軽度に認められた。一方, 乳頭部では 1 例に中等度, 2 例に軽度の慢性炎性細胞浸潤がみられた。

以上の所見より，肝内胆管，総胆管，乳頭部に括ける 組織変化はたがいに平行関係は明らかでない。胆管全体 の炎症と乳頭部の炎症は組織学的に反応を異にするよう に思われる，したがつて乳頭部の変化を胆管末端炎之独 立して把觉る解积が自然であるが，症例が少ないので結 論はひかえたい。原発性沉胆管炎, 続発性汎胆管炎之胆 管末端炎のような限局性病変との関係は多数の症例を得 て結論すべきであるう。

8. 十二指腸乳頭部組織変化と加齢との関係 剖検例を対象に，検索例31例について乳頭粘膜の变化 を加令飞注目してみると，乳頭部粘膜過形成珄变化の強 度のもの 4 例の平均年令は 50.7 歳, 中等度のもの 8 例の 平均年令は54.0歳, 軽度のもの12例のそれは53.7歳, 乳 頭部粘膜の萎縮をみるすの 7 例の平均年令は60.6歳であ つた．壁内腺管の変化と加令についてみると，壁内腺管 
增生型では增生高度例 3 例の平均年令が54.7歲，中等度 20例のそれは54.3歳, 增生軽度もしくは增生のみられな い症例 4 例のそれは55.2藏であつた。.のう胞形成型の 4 例の平均年令法57.5藏であつた．線維化の強さと加令と の関係についてみると，線維化高度 2 例の平均年令 は 57.0 墄, 中等度 2 例のそれは47.5歳, 軽度症例13例のそ れは59.1歳, 線維化のみられない症例14例の平均年令は 51.9歳であつた。線維化の有無と加令とについてみる 之, 線維化を認めた症例17例の平均年命は57.5歳で，線 維化の認められない症例の平均年令51.9歳より高年令で あつた。

以上より乳頭粘膜の過形成は年令とともにその程度が 軽度となり萎縮へと変化するようである，壁内腺管の増 生と加令についてはその変化が明らかでないが，のう胞 形成例は加令々関係があり高年令に多くみられた．線維 化の強さと加令については症例が少なく一定の結諭を導 くことができなかつたが，線維化の認められるものは， 線維化の認められないものより明らかに平均年令が高く みられた。つまり十二指腸乳頭部組織には粘膜上皮の過 形成之萎縮, 壁内腺管の增生抎張之のう胞形成, 線維化 のないものと線維化の認められるものとの間に年令との 関係が考虑される結果を得た。

\section{B. 検討成續からみた慢性乳頭资の分類}

乳頭炎について Del Valle ${ }^{\mathrm{i})}, \mathrm{Acosta}^{2)}$ ，梅園 ${ }^{31)}$ らの乳頭 形成術組織標本に基ずく分類が報告されている。著者も 乳頭形成術組織標本から乳頭部構成々分に基づいた観察 を行つて前述のような検討成績を得た。組織構成に基つ” く炎性変化を時間的推移を考慮して観察すると落 1 の項

\section{表 3 慢性乳頭炎の分類}

1. 過形成性乳頭炎

2. 腺のら胞性乳頭炎 腺管増生型 のう胞形成型

3. 線維性乳頭炎

I 度

II 度

III 度
5 例 $(16.2 \%)$

9 例 $(29.0 \%)$ 7例 2例

13例

2例

2例
目に示すようなつぎの 3 点が大切な変化であることを知 つた.すなわら粘膜上皮の過形成, 壁内腺管の增生・の ら胞形成と線維化・硬化である。陚みにこれを主眼に乳

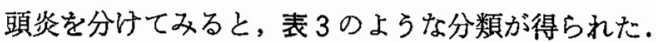
過形成性乳頭炎は乳頭粘膜上皮の過形成を主変化とし
組織構造は注ぼ正常に保たれ，間質の変化がほとんど認 められないものである. 症例 1 〜がこの範疇にあては まる。

腺のう胞性乳頭炎は壁内腺管の增生を主たる所見とし 間質の 線維化を認めないもので，壁内腺管の増生・拡 張を主所見とする腺管増生型とのう胞形成を主所見とす るのら胞形成型に分けることができる．症例 6 〜 14がこ れに相当する.

線維性乳頭炎は問質の線維化・硬化を主所見とするも ので, 線維化・硬化の程度により軽度 ( I 度)，中等度 (II 度), 高度 (III度) に分けられる.症例15〜31がこの 乳頭炎にあてはなる。

したがつて過形成性乳頭炎は 5 例 (16.2\%),腺のう胞 性乳頭炎は 9 例 (29.0\%), 線維性乳頭炎は17例 (54.8 \%)となり，線維性乳頭炎は54.8\%と半数以上を占め る.つまり外科的に乳頭资は線維化・硬化が最す重要な 所見と考学られる。なお線維性乳頭炎田度は，いわゆる 硬化性乳頭资にあたるものである。

\section{考按}

いわゆる十二指腸乳頭は十二指腸下行部の膵附着部に 位置し胆猝管の合流した排泄管を開口させる半球状に突 出した隆起として観察される。乳頭は胆膵管の合流管が 十二指腸壁内を貫通することによつて形成される粘膜 下の隆起つまり咬ひだか の中に明膫に露出するもの と，包皮状の輪状ひだにかくれて観察されるるのとがあ る. 総胆管は十二指腸下行部の後内壁で十二指腸獎膜筋 層を貫通するがその直前で細くなり管壁が肥厚する，こ の部位で萃管は後内側より近づき総胆管と同じ結合織で 包まれたをま漿膜筇層を通過し十二指腸を約 $1.0 \sim 1.5 \mathrm{~cm}$ 斜走して胆管と合流管を形成し十二指晹に開口する ${ }^{8)}$ 9). この胆膵管の合流による内腔の拡がりを1748年 Vater が Vater 唕室または乳頭膨大部(Ampulla of Vater) と命名 した.膨大部の存在については様々な議論がある. 1856 年 Bernard $^{10)}, 1889$ 年 Sappey ${ }^{11)}$ が実験的に膨大部の存在 を肯定したが，1893年 Schirmer ${ }^{12)}$ は胆膵管が別れて開 口するすのが半分以上あると述へ胆膵管共通の終末部が Vater 㮩室であるとの意見に反諭した。O Opie ${ }^{13)}$, Archibald $^{14)}$ によると胆膵管は約 $80 \%$ が共通管を形成し十二指 腸に開口し共通管の長さは70\%が 5 mまたは $5 \mathrm{~mm}$ あるという. Hand ${ }^{99}$ は胆膵管の共通管形成は80〜85\% と している．本邦では溝口 ${ }^{7)}$ が胆膵管開口部について剖 検例より解剖学的に微細な検討を行つている．溝口は Vater 憩室が乳頭開口部を尖頂とする円維形の空室とし 
军其 1

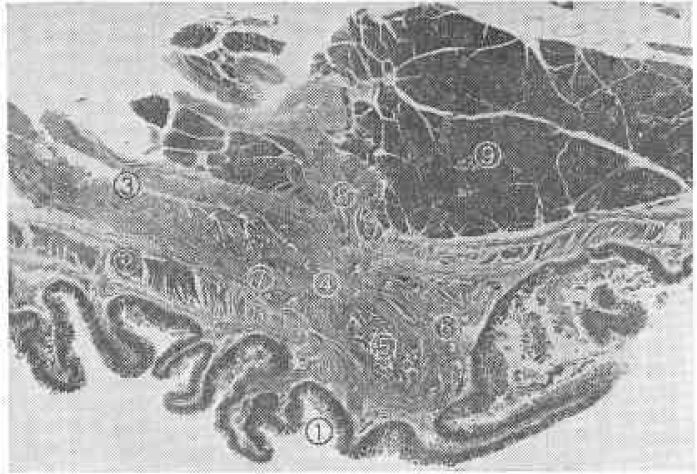

军卉10\%土ー马

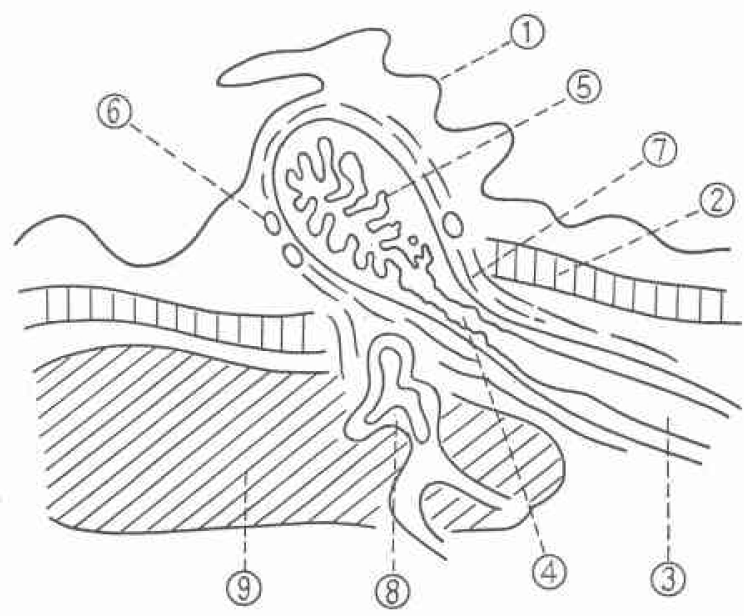

军真 2 のンェーー

(5)

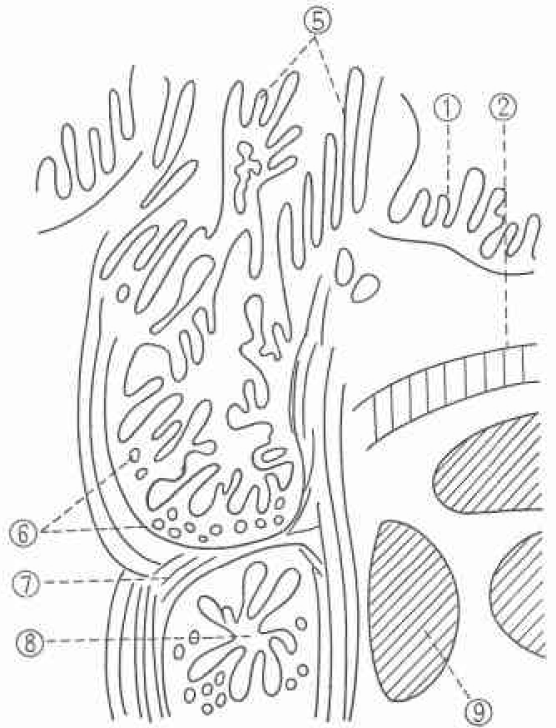

写真 2

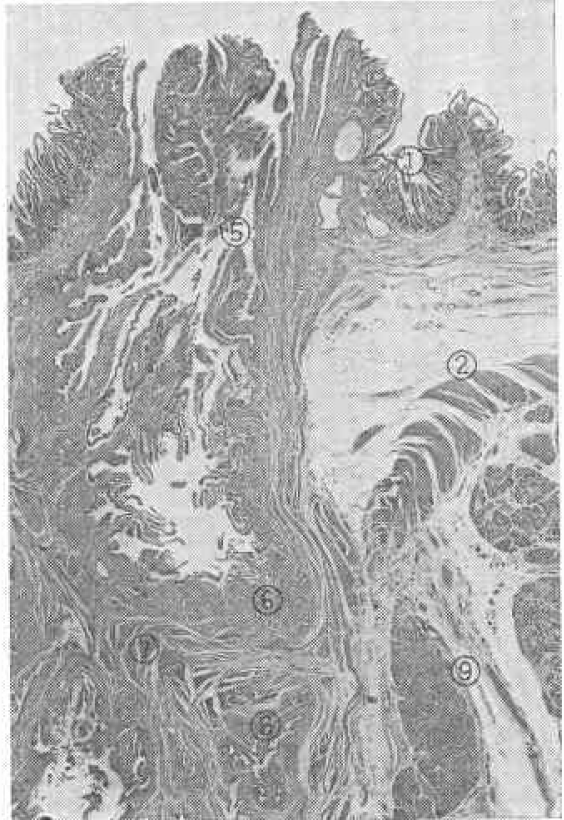

写真 3

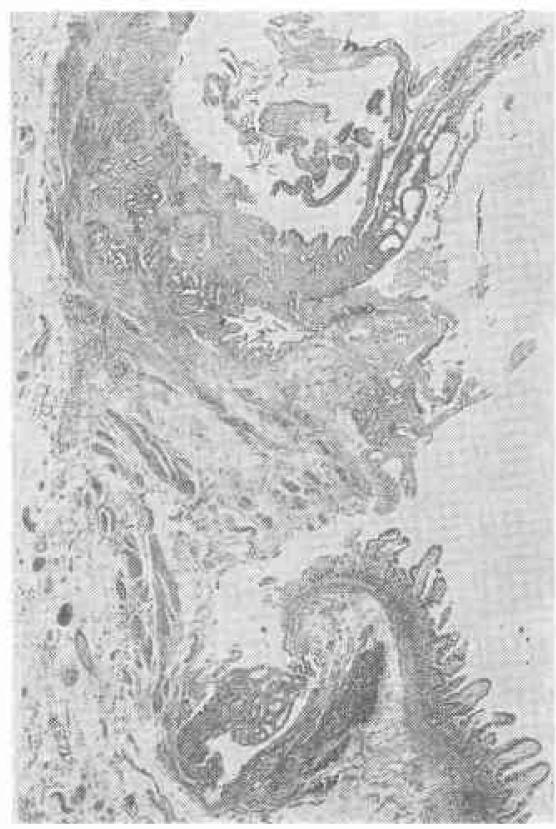


写其 4

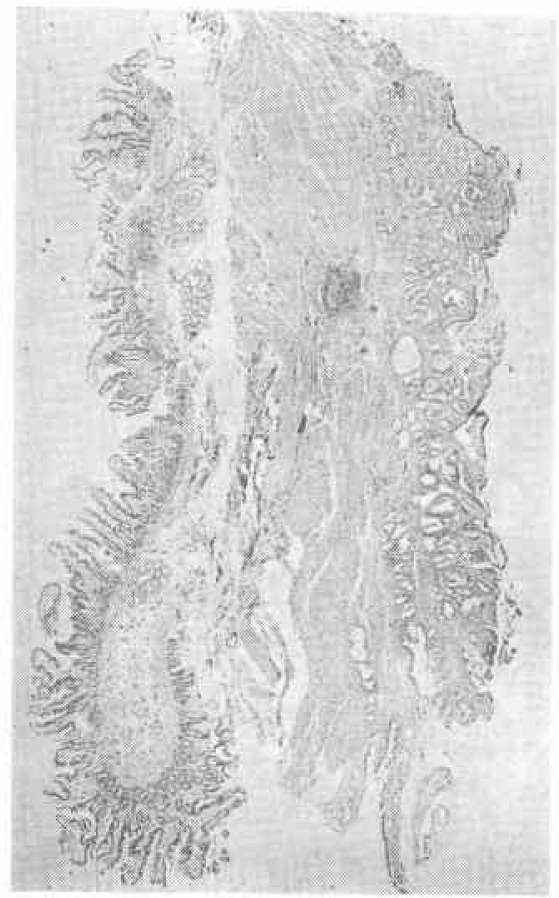

马真 6

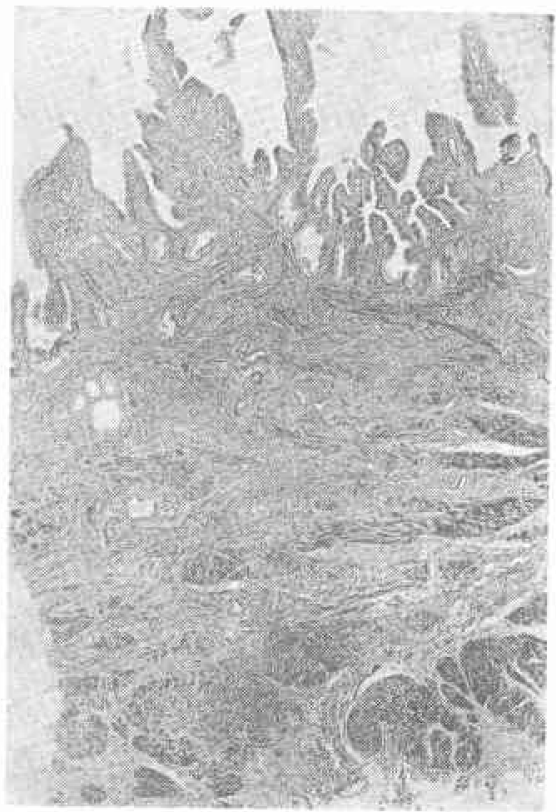

写真 5

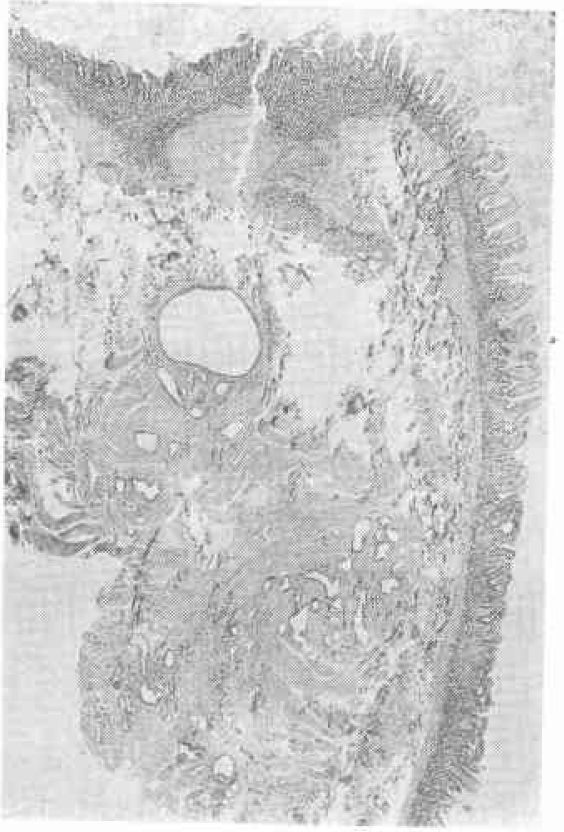

写真 7

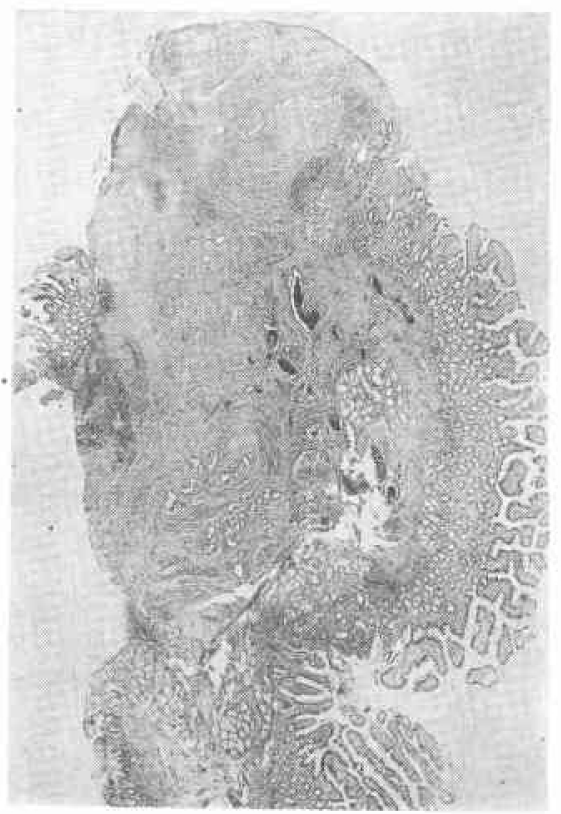


て認められ，その底边から頂点までは $2 \sim 6 \mathrm{~mm}$ (平均 $3.2 \mathrm{~mm}$ ) と報告している. 溝口によると胆膵管が合流し てあるいは単独に䕀室を作るもの約 $92 \%$ ，胆膵管が合流 するが憩室を作らないもの約 $4 \%$, 胆膵管が合流せず別 々に開口するもの約 4\%とし, Vater 勆室を作るものは 甚だ多いと報告している.山口 ${ }^{15)}$ は胆脺管が別々に開口 するのは $11.3 \%$ と報告して拉り本邦では胆脺管が別々に 開口することは少ないようである。

乳頭形成術施行の際，まず十二指腸切開後直視下に乳 頭を観察し乳頭開口部より胆脺管にそれぞれ择管し部位 を確認し，ついで胆管の前壁を縌軸11時の方向に 2.0 $2.5 \mathrm{~cm}$ 切開，十二指腸壁貫通による総胆管の生理的狭 窄部を充分含め乳頭部と十二指腸を楔状に切除している 16) 17)。この手続き中の観察によれば膨大部形成の明瞭な 症例はほとんどない。したがつて乳頭膨大部の名称を病 変の存在を示すために慣用的に用いているがその存在に ついては検討中である ${ }^{18) 199}$. 十二指腸乳頭の定義につい $\tau$, 日本人十二指晹乳頭の肉眼的形態を観察した溝口 ${ }^{7}$, 西井 ${ }^{20}$ らは解剖学的用語にのつとり乳頭部を肉眼的隆 起として考兄ている. Stering ${ }^{21)}$ ，Newman ${ }^{22)}$ は胆膵管 像との関連括よび肉眼的形態より, Poppel ${ }^{23)}$ ，服部 ${ }^{25)}$ は 十二指腸レ線像より，十二指腸乳頭は縦ひだを含めた範 囲としている.内視鏡的観察より, 中沢 ${ }^{24)}$, 小林 ${ }^{26)} ら る$ 十二指腸乳頭に縦ひだを含めている. 乳頭部の細部の名 称に関して大井 ${ }^{27)} ら の$ 提晿が一般に用いられているが， 十二指腸綎ひだの名称の定義も一定ではなく，したがつ て十二指腸乳頭の名称の確立は今後にまたねばならな い. 徳山 ${ }^{28)}$ は十二指腸乳頭の組織学的検討には胆管末端 部まで含めた考方方を示し，槙 ${ }^{29)}$, 中村 ${ }^{30)}$, 梅園 ${ }^{31)} ら$ Oddi 筋を含めた部位，すなわら十二指腸面からみれ ば縦ひだを含めた部位を乳頭部としている. Dowdy ${ }^{32)}$ は乳頭部の病態を考える場合, 縱ひだを含めて Vaterian System として扱つている，著者は肉眼的隆起を示す十 二指腸を胆道・膵・十二指腸のorgan complex としての 概念をとりいれた総胆管末端部として把握している.こ の総胆管末端部は乳頭形成術式により十二指腸粘膜, 乳 頭部粘膜とこれにつづく総胆管末端部粘膜の前壁を完全 な切片標本として得られる. 乳頭部は十二指腸開口部よ り総胆管の十二指腸壁貫通部までと定めて本稿での検討 を行つた. 対照の正常例では総胆管が十二指腸壁を貫通 している部位が明らかで，その部で総䏣管は生理的に狭 くなつている.輪状に囲まれた筋層で管壁が肥厚してい る状態も明らかである．総胆管の十二指腸壁貫通部の輪
状筋については，1654年 Glisson ${ }^{33)}$ が始めて述べている が，1887年 Oddi ${ }^{34)}$ が総胆管末端部をとり团む筋線維を 十二指腸筋と全くちがった筋線維群として発表した。 こ の Oddi 筋は1937年 Schwegler and Boyden ${ }^{35)}$ により発 生学的に立証された。

乳頭部粘膜は十二指腸粘膜と自然に移行するがその区 別は比較的容易である。しかし乳頭部腸上皮様粘膜と十 二指腸粘膜は区別しにくいことがある.十二指腸粘膜は 乳頭粘膜との移行部がやや丈が低くなつているがとくに 他の部位の十二指腸粘膜と変わることはない，乳頭部組 織構成を乳頭部粘膜, 粘膜下組織, 壁内腺管, 筋層とし た. 乳頭部粘膜は比較的密で丈が高く乳頭状あるいは䋐 毛状を呈し预壁ともいえる構造を形成する．乳頭部粘膜 下には粘液腺（壁内腺管）が存在する. 筋層は比較的発 達した縦走筋が主で輪状筋子観察できる. 乳頭部粘膜と 総胆管末端の粘膜は同じ一層の円柱上皮で自然に移行す るため, その区別は必ずしも明瞭でないが, 乳頭部粘膜 の丈が高いのに比べ胆管粘膜の丈が低くなつているため 多くの場合判別可能である.しかし乳頭部粘膜の過形成 のない.もしろ萎縮した症例ではその区別は困難である.

いわゆる十二指腸乳頭炎は急性炎と慢性炎に分けられ る。急性炎は炎症性反応により急性炎性細胞浸潤を中心 とする血管結合織反応をるたらすが，资症がとれれば炎 症の強さにより可逆的に炎症は消退し治癒するとされて いる ${ }^{2)}$. しかし炎症が強い場合，炎性びらん，浮腫膨 化, 潰瘍形成が起こり乳頭部に不可逆的な変化をきたす こともあるといわれる。ことにこれら急性炎が反復すれ ば慢性乳頭炎に移行することるあり得るとの見解があ る 2) 34). 著者の成績では純粋の急性炎例をとら兄ていな い, 乳頭部の急性炎性変化は結石嵌頓, 結石通過による 機械的制激が原因となる場合が多く，かつ慢性炎に重積 して認められた。つまり結石嵌頓による资症性反応によ つて単純な浮腫から線維化・硬化に至る変化が起こり慢 性に移行する場合もあるといわれ，結石の通過によつて 十二指腸乳頭部が損傷をうけ，後に痗痕を形成すること ああると報告されている234)。しかしこれらはいずれる 急性炎のみによつてもたらされるというよりは，むしろ 慢性炎の基盤の上に急性资珄変化が括よんで惹起する変 化と考えたい.

乳頭部は総胆管末端部の排泄管であるから胆管系, 脺 管系の刺激と腸管よりの刺激とを直接らけるため他の消 化管粘膜とは違つた刺激をらける可能性の多い部分であ る、したがつて単に総胆管の末端部として呼称せずに乳 
頭部としてこれを独立させて扱い，乳頭焱を観察するに あたつては隣接する十二指腸, 総胆管, 膵の変化をも把 握してorgan complex として動的な観察が必要である. したがつて病変としてとらえる場合, 乳頭部粘膜の変 化, 壁内腺管の変化, 間質拉よび筋層の变化の生理的反 応と病的変化とをいか炕とら劣るべきか, 組織学的变化 のどこまでを可逆的または不可逆的変化とするかが問題 であり，このことを考虑せずして慢性乳頭炎の解明は困 難であると考えられる。

Selberg ${ }^{36)}$ は正常乳頭部を組織学的に検索し平滑筋の 線維化, 腺の数, 㧓張などにつき個体差が著しいことを 報告, また加令との関俰を強調し乳頭炎の存在を疑問視 している. 本邦では梅園 ${ }^{31)}$ が乳頭部の慢珄炎症に関して 加令現象を無視しえないと記載している. Roux ${ }^{37)}$ は乳 頭部の腺萎縮, 線維化, 筋組織の変化を炎症といらより 退行性変性として迷べている。ここで検索した症例に抽 いて加令之組織変化を調べてみると，乳頭部粘膜の過形 成性は生理的反応としてらけとられ，加令によつて次第 に過形成より萎縮へと変わる過程がらかがわれた。壁内 腺管の增生については, 腺管増生型では加令との関係は みられなかつたがのう胞形成型症例では腺管增生型症例 に比べ，その平均年令も高く加令との関係がうかがわれ た. 間質の線維化についてる加令による線維化傾向がう かがわれた。壁内腺管の增生は乳頭粘膜上皮の反応つま り過形成性反応との相関が充分らかがわれるが, のう胸 形成がはつきりした症例飞はむしろ反応としてとら方る よりのう胞性変性としての退行像が強く認められた。

乳頭部病変の組織学的記載については, Benglea ${ }^{38)}$, $\mathrm{Hess}^{39)}$, Kaiser ${ }^{40)}$, Fuchsig ${ }^{38)}$, Acosta ${ }^{2)}$, Cattel ${ }^{41)}$, Paulino $^{42)}$, 中村 ${ }^{30)}$, 梅園 ${ }^{31)}$ らの報告をみるが，僈性乳頭炎 の組織学的特徵は, 炎症性細胞浸潤, 液痕性結合織増 殖, 筋の肥大增生を伴う腺増生の 3 つであるという ${ }^{43)}$. しかし諸家の報告からも慢性乳頭炎に和兴症と組織 変化の時間的推移を考慮しての乳頭炎の動的過程の把握 については充分な解析がなされていない，著者は乳頭部 粘膜, 壁内腺管, 間質, 筋層それぞれの変化飞ついて検 討し，それぞれの変化についての関係をみた。炎性刺激 により乳頭粘膜, 壁内腺管, 筋組織と間質は, それぞれ 過形成から萎縮へ, 增生・拡張からのう胞形成さらに变 性へ, 組織全体としてみればついには線維化・硬化に至 る組織学的病的経過が観察された（図１）.刺激が持続す る場合, 反復される場合, 時間の経過ととるに間質の線 維化が増加してくると思われ，乳頭部の变化はこの時は
じめて病変として臨床的にも意味がでてくると考えられ る. 乳頭部の炎症が原因する間質の線維化による器質 的狭窄性病変は Cattel ${ }^{41)}$ の報告以来広く認められてお

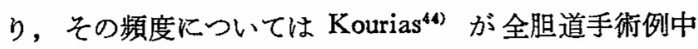
$3.8 \%$ Paulino $^{42)}$ は2.4\%, Thomas ${ }^{45)}$ は10.8\%, Hess ${ }^{30)}$ は29.4\% と記載している.間質の結合織増生・線維化に ついては Paulino ${ }^{42)}$ が23例中 8 例, Acosta ${ }^{2)}$ が61例中20 例, 中村 ${ }^{30)}$ が 20 例中 18 例と報告しているが著者の検討 した症例では31例中17例 (54.8\%) に線維化を認めた。

慢性乳頭炎については1926年 DeI Valle ${ }^{1)}$ が初めて慢 性洀痕性炎症による胆道末端部狭窄が総胆管の結石之関 係なく存在することを報告した. Hess ${ }^{39)}$ は胆道疾患の随 伴炎症でない独立した疾患として原発性乳頭资の存在を 報告して㔚り，その頻度は約 $8 \%$ で大部分は二次的な乳 頭炎であるとしている。一般に間質の線維化は慢性炎の 経過に颃いて結石と関係なく括こる原発性の場合と胆石 症の合併症として，つまり破壊性病変によつてもたらさ れる続発性の変化として現われる場合があると考兄られ る.この線維化を強める因子としては著者の検討例であ 結石など機械的刺激によるびらん，潰瘍形成など壞破的 因子によることが多い。間質に線維化の伴ら場合，これ は不可逆的変化であり, 病変としての意義は組織のみな らず機能面からも強くなつてくる。つまり乳頭部は炎症 の強さのみでなく間質の線維化しいては硬化像に最も注 目して評価されるべきであると考光る，症例17，21，25 はいずれる術前 sclerosing papillitis と診断し胆管拡張 に対する乳頭形成術を行つた症例であるが，3例ともに 間質の線維化を軽度ながら認めている，とくに症例17， 25は結石の既往歴もなく原発性乳頭炎之考えてよいと思 われる、乳頭炎が総胆管の限局性炎症であるか, 沉胆管 炎であるかとついて種々の議論がある. Partington ${ }^{46)}$ は 肥厚性狭窄部位が一般飞括的筋領域に限局して観察され る事実から，慢性胆管炎による全総胆管壁肥厚の部分現 象が乳頭炎であるとする見方疑問があるとしている。 著者は肝内胆管, 総胆管, 乳頭部の組織標本が得られた 3 症例についてその組織変化をみたが，その組織変化は たがいに平行関係が明らかでなく，胆管全体の炎症と乳 磌部炎症は組織学的に反応を異にする様に思われた。し たがつて, 乳頭部の変化を胆管末端炎と独立して把兄る 解釈が自然であるが症例が少ないので結論はひか充た い. 原発性沉胆管炎, 続発性沉胆管炎々胆管末端炎のよ らな限局性病変との関係は多数の症例を得て結論がださ れるべきと考苀る。 
慢性乳頭炎の組織学的特徵㳊筋肥大增生を伴う腺增生

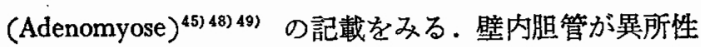
に筋層内に侵入増生の像 (腺症) ${ }^{48)}$ 49) 6 例にみたがそ れに伴なら筋肥大の症例はみられず，6 例中 2 例にはさ しろ筋線維の萎縮をみた．この腺症をみた 6 例はすべて 壁内腺管增生・拡張・のう胞形成の症例で乳頭粘膜過形 成を主所見とする症例, 線維化のみを主所見とする症例 にはみられなかつた。いわゆる腺筇症と思われる症例は なく, 著者の症例関する限りでは壁内腺管の筋層内一 の侵入増生は主変化といらよりは, むしろ過形成性から 壁内腺管增生性, のう胞形成性さらには線維化・硬化に 至る変化の経過中にみられる炎症経過のある断面と考只 られる。

乳頭部への細胞浸潤はリソパ球, プラスマ球が主体で あるが，線維化・硬化の強い慢性乳頭炎では細胞浸潤は 強くない.つまり, 病変として一番強い変化をきたした 線維化・硬化像の乳頭炎では細胞浸潤という意味で炎症 は軽いといらことになる。したがつて, 资症の強さは炎 症の推移の途中では問題となるが時間的経過を考慮すれ ば，線維化・硬化をきたした場合組織のエネルギーは低 下乙炎症はごく軽度で反応性変化も活とんど認められな い.この変化は慢性乳頭炎の終末像として大きな意味を もつと考学れる。

乳頭炎の分類について下記の様な報告がある.

Del Valle と上る慢性乳頭炎分類

1. Papillits hypertrophica

2. Papillitis atrophica

3. Papillitis erosiva

4. Papillitis cholesterosica

5. Papillitis vegetante

6. Papillitis fagedenica

Acosta Kよる慢性乳頭炎分類

1. chronic ulcerous Papillitis

2. chronic granulomatous Papillitis

3. chronic adenomatous Papillitis

4. chronic sclerosing Papillitis

梅園による乳頭炎分類

I 型 (正常型)

II 型 (水腫型)

III型 (急性炎型)

$\mathrm{IV}$ 型 (腺增生型)

田辺による乳頭部病変の分類

I 型：炎症型
II 型 : 線維・腺增生型

而型 : 腺症型 (腺筋症型)

これら乳頭桨分類をみると, 組織学的変化と肉眼的形 態が混じて分類され純粋な組織学的分類といい難いる の, 現象をとらえた組織学的分類で，著者が随伴性現象 であると考えた結石による潰演や肉芽組織に注目して分 類したるの，著者の重視する線維化・硬化に対しても充 分な表現がみられないるのなどである. Del Valle が慢 性廐痕性炎症尤る胆道末端部狭窄を sclerosing choledocho-odditis と報告して以来, Acosta ${ }^{2)}$, Kourias ${ }^{4(4)}$, Na$\mathrm{rdi}^{50)}$ らによつて慢性硬化性乳頭炎が常に問題とされて きたが，著者の線維性乳頭炎度がこの硬化性乳頭炎飞 相当する. 前述の分類ではこの位置づけも不明確で比較 検討がしにくい，炎症と組織变化の時間的推移について 配慮に乏しいようである. 田迅 ${ }^{48}$ による乳頭部病変の分 類は剖検例飞よる病型分類であるが, 腺症 (腺笳症) が 大きくとりあげられている．著者の検討症例に関する限 りでは, 壁内腺管の筋層内への異所性侵入增生 (腺症) は主変化というょりは, むしろ過形成性から壁内腺管增 生性,のう胞形成性さらには線維化・硬化洷る変化の 経過中にみられる炎性経過の断面と考兄られる。これら 腺症症例に筋肥厚を伴なら症例はみられず，いわゆる腺 筋症と思われる症例はなかつた。

因 1 慢性乳頭炎の経過

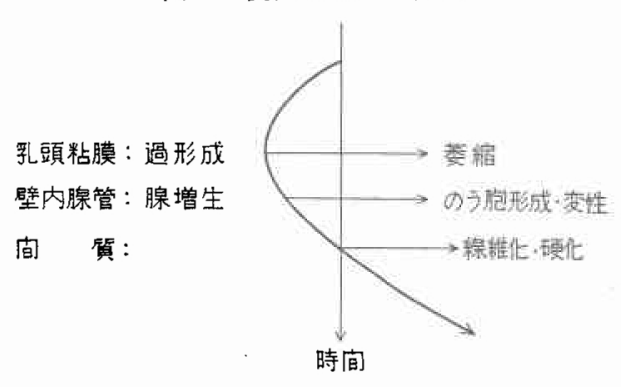

著者の分類の特徴は，炎性変化と乳頭部組織の反応な いし病変との関係を時間的推移を加味して分類したこと にある. 生体の基本的反応態度を考慮して時間的経過を たどれば，図1のような経過が考兄られる。この経過は 著者の分類とも合致するもので慢性乳頭炎を把握するた めに重要な過程と考える。

\section{結 語}

1）乳頭部の組織所見をその組織構成に基づいて検討 した.

2）乳頭粘膜の過形成は乳頭部組織全体の過形成と平 
行する。

3）壁内腺管は炎性刺激によつて增生・拡張しさらに のう胞形成・変性に至る.

4）間質の線維化・硬化は $54.8 \%$ にみられ外科的乳頭 炎では最も重要な所見と考学られる。

5）炎性細胞浸潤の程度は炎症の強弱を現わするので 乳頭部組織変化と必ずしも一致しない. 急性炎性細胞の 出現には破壊性病変と関係するものが多く慢性炎に重積 して観察された。

6）乳頭部の炎性変化と十二指腸のそれとは必ずしも 一致しない.

7）びらんまたは漬瘍の破罗性病変は結石によつても たらされた修飾的病変で本来の炎症を強めゆがめる働き をする，これは間質の線維化・硬化を促進する。

8）腺症 (腺䇗症) は組織の主変化といらょりをしろ 過形成性から線維化・硬化至る変化の経過中にみられ る资症経過の断面之考兄られる.

9）肝内胆管, 総胆管, 乳頭部に招ける炎性組織変化 の平行関係は明らかでない，胆管全体の炎症と乳頭部炎 症は組織学的に反応を異にすると思われ乳頭部の変化を 胆管末端炎と独立して把える解釈が自然と考えられるが 結論は下せない。

10）年令と乳頭部組織の粘膜上皮の变化, 壁内腺管の 変化, 間質の線維化との間闰関係がある.

11）胆道疾患に随伴しないいわゆる原発性乳頭炎と思 われる症例は 2 例であつた。

12）乳頭部組織すなわち乳頭部粘莫, 壁内腺管, 間質 が炎性刺邀によつて過形成から萎縮, 線維化・硬化へと 変化してゆく過程が理解された。

13）著者は慢性乳頭炎を生体の基本的反応を考虑し， 炎性変化と乳頭部組織の反応ないし病変との関係に時間 的推移を加味して, 過形成性乳頭炎, 腺のう胞性乳頭 炎, 線維性乳頭炎の 3 型に分類した。

（稿を終るに南たり，本研究の機会を与えてご䩒撻下 さった中山恒明所長, 遠藤光夫教授, 羽生富士夫教授, 浜野恭一助教授に感謝するとともに，直接ご指導，ご校 閲を賜わつた渑原教授，鈴木博孝講師に心から感謝す ๖. )

\section{写真説明}

写真 1 : 正常乳頭部組織 (H.E. 染色) 58 合

写真 2 : 正常乳頭開口部 (H.E. 染色) $45 \hat{\text { o }}$

写真 1, 2 の説明

(1) 十二指腸粘膜
(2) 十二指腸筋層

(3) 総胆管

(4) 総胆管末端生理的狭窄部 (十二指腸壁貫通部)

(5) 乳頭部 (粘膜)

(6) 乳頭部壁内腺管

(7) オーディー筋

(8) 膵管

(9) 膵藏

写真 3 : 乳頭粘膜上皮の過形成 (H.E. 染色) 症例4) 61 委

写真 4 : 壁内腺管の増生, 拡張 (H.E. 染色) 症例12) 54 우

写真 5 : 壁内腺管の5胞形成 (H.E. 染色) 症例28）65今

写真 6 : 間質の線維化, 硬化 III度 (Azan-Mallory染 色）症例29）65오

写真 7 : 潰瘍形成, 間質の線維化 II 度 (H.E. 染色) 症例16) 53 우

\section{文献}

1) del Valle, D., Donovan, R.: Colédoco-Odditis retráctil crónica concepto clinico y quirurgico. Arch. argent. Enferm. Apar. Digest., 1: 605$620,1926$.

2) Acosta, J.M.: Papillitis., Arch Surg., 92: 354, 1966 .

3) 槙哲夫：日本人胆道疾患と乳頭炎の問題, 外 科, 20 : 529-533, 1959 。

4) Spalteholz, W.: Handatlas der Anatomie der Menschen, 607, S. Hirzel, Leipzig, 1933.

5) Brous, H.: Anatomie der Menschen, 278, Springer, Berlin, 1956.

5) 金子丑之助：日本人体解剖学, II, 71, 南山 堂, 東京, 1968.

7) 溝ロ一枝 : 日本人十二指腸の肝膵管開口部の解 剖学的研究. 昭和医学会雑誌, 20：549-564, 1960.

8) 現代外科学大系, $38 \mathrm{~A}, 41-43$, 中山書店, 東 京, 1972 .

9) Hand, B.H.: An anatomical study of the choledochoduodenal area, Brit. J. Surg. 1: 486-494, 1963.

10) Bernald, C.: Mémoire sur le pancréas, Paris, 1856.

11) Sappey, M.P.C.: Traité d'anatomie descriptive, 4: 272, Paris, 1889.

12) Schirmer, A.M.: Inaugural Dissertation, Basle University, 1893.

13) Opie, E.L.: The etiology of acute hemorrhagic pancreatitis, Bull. Johns Hopkins Hospital, 12: 182, 1901.

14) Archibald, E.: Ideas concerning the causa- 
tion of some cases of pancreatitis, Canad. J. Med. Surg., 33: 263-271, 1913.

15) 山口寛: 邦人胆系の局所解剖知見, 解部学雑 誌, 3：193-229, 昭5.

16) 羽生富土夫汪か：経十二指腸乳頭形成術，外科 治療, 28：643-646,1973

17) 羽生富士夫ほか：乳頭形成術の問題点, 外科, $35: 1310-1316,1973$

18)福田武隼ほか：乳頭膨大部癌の病理学的検討, 第58回日本消化器病学会総会で発表, 1972.

19)福田武隼ほか：乳頭膨大部癌の臨床病理学的検 討 (切除標本16例について), 第 4 回日本消化器 外科学会で発表, 1974 .

20)西井啓二：十二指腸乳頭の形態学的䔘察，日本 外科宝函, 32：418-426,1963.

21) Stering, J.A.: Significant facts concerning the papilla of vater, Am. J. Dig. Dis., 20: 124-126, 1953.

22) Newman, H.F. et al.: The papilla of vater and distal portions of the common bile duct and duct of wirsung, Surg. Gyn. Obst., 106: 687694, 1958.

23) Poppel, M.H. et al.: The roentgen aspects of the papilla and ampulla of vater, Springfield, Illinois, Charles C. Thomas, 1953.

24）中沢三郎注か：十二指腸乳頭部に関する内視鏡 的考察, Gastenterogical Endoskopy 13:227234,1971 .

25）服部外志之：十二指腸乳頭部に関するレ線的研 究，日消会誌，68：263-282,1971

26) 小林絢三ほか：十二指腸乳頭炎の臨床的研究, 日消会誌, 69：1265-1279，1972.

27) 大井 至, 竹本忠良：十二指腸乳頭の名称, 胃 之腸, $6: 1174,1971$.

28) 徳山武郎 : ファーター乳頭部領域の病理組織学 的知見補遗, 順天堂医学, $12: 77-95,1966$.

28) 槙哲夫ほか：胆道疾患に対するファーター氏 乳頭部分的切除術之乳頭部の病理組織学的変 化, 臨床外科, $12: 65-73,1957$.

30) 中村 豊: 各種胆道疾患, 特飞胆管拡張例飞徖 ける十二指腸乳頭部の病理組織学的研究, 日外 会誌, $61: 1219-1227,1960$.

31）梅園 明ほか: 胆石症, 胆のら炎に対する释十 二指腸乳頭成形術, 手術, 22: 1101-1107, 1968.

32) Dowdy, G.S. Jr.: The biliary tract, Philadelphia, Lea \& Febiger, 1969.

33) Glisson, F.: Anatomia Hepatis. O. Pullein, London, 1654.

34) Oddi, Rugero: D'un disposition a sphincter spécial de l'ouverture du canal cholédoque,
Arch. ital. Biol., 8: 317--322, 1887.

35) Schwegler, R.A. Jr. \& Boyden, E.A.: The development of the pars intestinalis of the common bile duct in the human fetus, with special reference to the origin of ampulla of vater and sphincter of oddi, Anat. Rec., 67: 441-468, 1937.

36) Selberg, W.: Das morphologische Substrat der sogenannten papillitis stenosans cholangica, Zbl. Allg. Path., 96: 551-554, 1957.

37) Roux, M., Rettori, R.: Roentgen and pathologic appearance of chronic odditis. J. Int. Coll. Surg. 32: 599-612, 1959.

38) Fuchsig, P., Hartmann, G.: Zur kenntnis gutartiger stenose der papilla vateri. Wien. Med. Wschr., 108: 937-939, 1958.

39) Hess, W.: Die stenosierende papillitis. Chir. Praxis, 1: 23-38, 1957.

40) Kaiser, E.: Die papillitis stenosans. Praxis, 45: 449-457, 1956.

41) Cattel, K.B., Colcock, B.P.: Fibrosis of the sphicter of oddi, Ann. Surg., 137: 797-806, 1953.

42) Paulino, F., Cavalcanti, A.: Biopsy of the ampulla of vater for demonstration of organic stenosis. Surgery, 48: 698-705, 1960.

43) 三宅 博: 胆石症, $182-186$, 金原出师, 東 京, 1970.

44) Kourias, B. und Papacharalampous, N.: Die chronische pankreatitis als begleiterkrankung des Gallensteinleidens. Chirurg., 37: 11-16, 1966.

45) Thomas, C.G. Jr., Womack, N.A.: Acute cholecystitis, its pathogenesis and repair. Arch. Surg., 64: 590-600, 1952.

46) Partington, P.F.: Fibrotic stenosis of the terminal common duct, Surgery, $31: 367-372$, 1952.

47) Dardinski, V.: The anatomy of the major duodenal papilla of man with special reference of its musculature, J. Anat., 69: 469-478, 1935.

48)田辺俊之：胆道と膵の関連を含む良性乳頭部病 变について, 剖検症例による検討, 日消会誌, 71 : $973-987,1974$.

49) Kourias, B.G. and Tierris. E.J.: Transcluodenal sphincterotomy with strict Indications, Am. J. Surg. 112: 426-431, 1966.

50) Nardi, G.L., Acosta, J.M.: Papillitis as a cause of pancreatitis and abdominal pain, Annals of Surgery, 164: 611-621, 1966. 